\title{
DESCOLONIZAÇÃO JURÍDICA DAS ASSOCIAÇÕES PELAS PRÁTICAS SOCIOCULTURAIS: A EXPERIÊNCIA DAS QUEBRADEIRAS DE COCO BABAÇU DO MARANHÃO E DOS PIAÇABEIROS DO AMAZONAS
}

\author{
LEGAL DECOLONIZATION OF ASSOCIATIONS FOR SOCIO- \\ CULTURAL PRACTICES: THE EXPERIENCE OF COCO BREAKS \\ BABAÇU OF THE MARANHÃO AND PIAÇABEIROS OF AMAZONAS
}

Luciano Moura Maciel'

\begin{abstract}
RESUMO: O artigo objetiva analisar a relaçăo entre o colonialismo do Direito no Brasil diante da obrigatoriedade da constituiçăo de associaçóes pelos povos e comunidades tradicionais para terem a possibilidade de lutar pela efetivaçăo de seus direitos territoriais, ambientais, étnicos e culturais. O Estado brasileiro exige para a conquista de direitos, sejam de titulaçăo de propriedade, luta por demarcaçăo e obtençấo de financiamentos, a constituiçăo de associaçôes para efetivaçăo de direitos coletivos de grupos étnicos, estas associaçōes sâo de direito coletivo diferenciam-se das associaçôes de direito civil cuja forma de regulaçăo pode divergir inteiramente dos modos próprios de organizaçâo social e jurídica dos grupos sociais. A metodologia utilizada será da coleta de material bibliográfico sobre colonialismo e descolonialismo do direito e pesquisa direta e indireta de campo utilizando os dados e entrevistas colhidos no campo, alusivos às experiências em associaçōes das quebradeiras de coco babaçu no Estado do Maranháo e dos piaçabeiros do médio Rio Negro Estado do Amazonas.
\end{abstract}

Palavras-Chave: descolonizaçăo; povos e comunidades tradicionais; quebradeiras de coco; piaçabeiros.

ABSTRACT: The article aims to analyze the relationship between the colonialism of law in Brazil before the obligation of the constitution of associations by the traditional peoples and communities to have the possibility to fight for the realization of their territorial, environmental, ethnic and cultural rights. The Brazilian state demands for the conquest of rights, whether of titling of property, struggle for demarcation and obtaining of financing, the constitution of associations for the realization of the collective rights of ethnic groups, these associations are of collective right differ from the associations of right whose form of regulation may diverge entirely from the proper modes of social and legal organization of social groups. The methodology

1 Mestre em Direito Ambiental pela Universidade do Estado do Amazonas, Doutorando em Direitos Humanos e Meio Ambiente pela Universidade Federal do Pará. Bolsista Capes. Advogado. advlucianomoura@gmail.com 
used will be the collection of bibliographic material on colonialism and decolonialism of the law and direct and indirect field research using the data and interviews collected in the field, allusive to the experiences in associations of the babaçu coconut breakers in the State of Maranhăo and the piaçabeiros do medium Rio Negro State of Amazonas.

Keywords: decolonization; Peoples and communities; Coconut breakers and piaçabeiros.

\section{INTRODUÇÃO}

A colonizaçăo para Fanon (1968, p. 30) foi conduzida pela violência, exploraçăo e assassinato do colonizado pelo colono por meio de baionetas e canhóes vindo a destruir formas sociais indígenas, arrasando seus sistemas próprios de economia, os modos de aparência, provocando dentre tantas mazelas, o deslocamento compulsório dos colonizados nas cidades, após serem expulsos de seus territórios tradicionais processo simultâneo com o processo político, racional e cultural da Modernidade caracterizada pela expulsăo dos povos mouros da península ibérica em 1492, data do "encobrimento do outro" com a ocupaçáo da América. Neste processo histórico, a Modernidade afastou, desprezou e excluiu a natureza, separando direito individual e coletivo, contrapondo sociedade civil e natureza e impondo o direito de além-mar aos povos das Américas (TÁRREGA e GONÇALVES, 2016; DUSSEL, MARÉS, 2015)

Neste ponto, o artigo problematiza a questâo da imposiçăo da forma jurídica positiva das associaçôes aos povos indígenas e comunidades tradicionais, no sentido de refletir se náo é uma forma de deterioraçăo das formaçôes sociais dos grupos sociais que passaram por extremo processo de colonizaçâo no sentido de Fanon? As experiências dos grupos no formato de associaçōes jurídicas náo seria o modo contemporâneo de desarticulaçâo das formas de organizaçâo jurídica específica dos povos indígenas e comunidades tradicionais?

Diante da problematizaçăo formulada o artigo objetiva analisar a relaçăo entre colonialismo, colonialidade e o direito diante da imposiçấo aos grupos sociais de constituírem a forma jurídica de associaçōes. De modo específico, o artigo objetiva a partir de pesquisa empírica verificar as formas de apropriaçâo e reapropriaçăo do instituto das associaçóes pelas quebradeiras de coco babaçu do Maranhăo e os piaçabeiros do médio Rio Negro no Estado do Amazonas.

As quebradeiras de coco babaçu se autodefinem socialmente e politicamente pelas atividades comuns de extrativismo do coco babaçu, constituindo-se em um grupo de mulheres oriundas de um campesinato formado por descendentes de negros escravizados, de índios destribalizado e de nordestinos deslocados. Este grupo social exerce suas atividades nos Estados do Pará, Maranhăo, Piauí e Tocantins. (PORRO, 2002, p.11). ${ }^{2}$

2 A pesquisadora e Professora Noemi Porro em sua tese de doutorado em Filosofia pela Universidade da Flórida em 2002, intitulada "Rupture and resistance: gender relations and life trajectories in the babaçu palm forests of brazil", detalha as origens das quebradeiras de coco babaçu enquanto descendentes dos escravos nativos de diferentes tribos africanas da Costa da Guiné, Cabo Verde, Angola e provavelmente do Sudâo e da Etiópia e de indivíduos destribalizados oriundos das naçóes indígenas Timbiras, Kanela e Guajaras, que foram miscigenados com Europeus na sua maioria de Portugal, França e Holanda e com Libanês. 
Os piaçabeiros sâo sujeitos sociais que se autoidentificam e săo identificados como aqueles que detêm o conhecimento específico de cortar, beneficiar e extrair a piaçaba revelando domínio de um manejo criterioso e sustentável em relaçáo ao piaçabal oficialmente definido pela incidência da palmeira de piaçaba, as chamadas "piaçabeiras" que se situam as margens dos igarapés, subafluentes dos rios. É no piaçabal que as relaçóes complexas atreladas a prática extrativista se estabelecem entre os piaçabeiros e os patrôes caracterizado por um sistema muitas das vezes análogo a escravidăo considerando o acúmulo de dívidas do piaçabeiro em relaçăo ao "patrâo" (MENEZES, 2012, p. 18/93).

Ambos os grupos sociais sofrem na contemporaneidade o reavivamento do processo colonial de submissáo às leis modernas que garantem a propriedade privada no Brasil e na América Latina. Este fato tem sua origem no genocídio dos povos indígenas (CHIVI VARGAS, 2009, p. 153), desde chegada do colonizador no Brasil, quando as terras indígenas passaram a pertencer a Portugal, em nome de Deus e do Rei.

Pensar em descolonizaçăo jurídica nos remete a compreender as origens do direito moderno imposto aos povos colonizados nas Américas mediante o uso da força e da violência pela colonizaçấo externa de povos com diferentes identidades que habitavam território comum, bem como pela colonizaçăo interna que nâo passou de substituiçăo do sujeito dominador ativo da violência, dos agentes da lei e da ordem do Estado Português para agentes do Estado nacional brasileiro, pois, deixar de ser colônia de Portugal nâo significou para o Brasil um processo de descolonizaçăo jurídica, econômica e cultural (ASSIS; 2014. COELHO; 2002).

O artigo inspirado pelas vivências associativas dos povos e comunidades tradicionais, especialmente das quebradeiras de coco babaçu do Maranhăo dos piaçabeiros na regiâo do médio Rio Negro no Amazonas, traz a lume a realidade sociocultural de grupos sociais, que incorporaram fatores étnicos, lutas ecológicas preservacionistas e de acesso aos recursos naturais na dinâmica das associaçôes criadas, grupos estes, outrora invisíveis para o direito moderno capitalista, formam associaçōes diferentes das associaçôes civis abstratas de cunho liberal prevista na dogmática jurídica.

O espaço social da associaçâo năo é mero agrupamento de indivíduos para fins comuns, consoante informa a regulaçăo civilista, a qual a associaçăo seria um direito potestativo do indivíduo oponível em face de todos e do Estado, no campo do exercício de sua liberdade individual, assegurando o direito de associar-se, permanecer associado ou deixar de sê-lo. Pelo estudo e observaçâo das práticas associativas das quebradeiras de coco babaçu e dos piaçabeiros, as associaçōes săo instrumentos jurídicos apropriados pelos grupos sociais, em observância à própria imposiçăo Estatal, como é o caso da titulaçăo de propriedade das terras tradicionais dos povos quilombolas. Revelam modos de criar e fazer coletivo fundado em experiências compartilhadas dos sujeitos que compóema entidadeassociativa, com uma finalidade essencial:garantir direitos territoriais.

Realizamos uma opçâo teórica neste artigo em utilizar a categoria jurídica ${ }^{3}$ de povos e comunidades tradicionais para designar concretamente os povos indígenas,

3 Ver categoria jurídica em CRETELLA JÚNIOR, José. As categorias jurídicas e o direito administrativo. Revista de Direito Administrativo, v. 85, p. 28-33, 2014. Disponível em<http://bibliotecadigital.fgv.br/ ojs/index.php/rda/article/viewFile/28805/27657>. Acesso em 27 de setembro de 2014. 
quilombolas, quebradeiras de coco babaçu, piaçabeiros, seringueiros, faxinalenses, comunidades de fundo de pasto, ciganos, geraizeiros, pescadores artesanais e diversos outros sujeitos emergentes, a explicaçăo nâo decorre exclusivamente da adscriçăo ao conceito legal previsto no Decreto 6.040/20074. Mas por influência dos escritos de Almeida (2007) que prefere a utilizar "comunidade", em sintonia com a ideia de "povos tradicionais", deslocando o termo "populaçôes" năo apenas pelo seu caráter de corpos teóricos da biologia como observou Faria (2006, p. 20), mas por se referir a um aspecto quantitativo de um conjunto de pessoas, com menor referência a aspectos culturais e étnicos que o termo "povos" denota. O termo "tradicional" ganhou força como reivindicaçấo do presente por se aproximar com as dinâmicas de mobilizaçăo e năo pela repetiçăo de práticas ancestrais ou pela transmissâo de traços culturais (ALMEIDA, 2007).

Neste contexto, o primeiro capítulo propōe estudar a relaçăo entre colonialismo, colonialidade e a formaçâo do direito brasileiro baseado em uma episteme eurocêntrica problematizando o viés hierárquico do direito oficial do Estado na imposiçăo de suas categorias ortodoxas, universais, liberais.

No segundo tópico, desenvolvo a relaçăo entre associativismo e reconhecimento jurídico problematizando o reconhecimento jurídico realizado por categorias do direito privado preexistentes ao reconhecimento Constitucional dos povos indígenas e comunidades tradicionais, como é o caso das associaçōes jurídicas.

Na segunda parte, o artigo inicia sua parte empírica com fundamento na pesquisa de campo realizada junto às quebradeiras de coco babaçu da regiăo do Estado do Maranhăo, nos municípios de Lago do Junco e Esperantinópolis,estudando as associaçôes como uma organizaçâo jurídica, política, ambiental e cultural, fundamental para os processos de lutas e reinvindicaçôes ambientais e sociais das quebradeiras de coco babaçu.

Por conseguinte, também com foco empírico, mas utilizando-se de fontes indiretas de pesquisa de campo, o artigo busca realçar as experiências com associaçōes dos piaçabeiros do médio Rio Negro no Estado do Amazonas, até para vislumbrar diferentes formas de apropriaçăo das associaçôes e de seu uso político. Em outras palavras, cada grupo social ressignifica, atualiza e dinamiza o uso das associaçōes de forma diferenciada, năo é forçoso constatar que o teor normativo do código civil ao regular de forma universal para todas as associaçóes petrifica o instituto no tempo e no espaço.

\section{COLONIALISMO E COLONIALIDADE DO DIREITO NO BRASIL}

O processo colonizador lusitano no Brasil significou para o Direito a imposiçăo de institutos jurídicos exógenos aos povos indígenas, uma cultura jurídica vista como superior centrada nos valores jurídicos provenientes da tradiçâo do Direito Português e o seu corpus de normas legislativas tornaram-se a base exclusiva do Direito pátrio.

4 Segundo art. $3^{\circ}$ do Decreto n. ${ }^{\circ}$ 6.040, de 07 de fevereiro de 2007, povos e comunidades tradicionais sáo; grupos culturalmente diferenciados e que se reconhecem como tais, possuidores de formas próprias de organizaçáo social, ocupantes e usuários de territórios e recursos naturais como condiçấo à sua reproduçâo cultural, social, religiosa, ancestral e econômica, utilizando conhecimentos, inovaçôes e práticas gerados e transmitidos pela tradiçáo. 
No contexto de criaçăo do Direito brasileiro o colonizador Português desconsiderou completamente a contribuiçăo dos povos indígenas para o Direito, o indígena era objeto de uma regulaçáo servil e escravocrata possibilitando os processos genocidas e sua desintegraçăo cultural. (WOLKMER, 2002, p. 46)

De modo cruel, os povos negros atualmente reconhecidos pela Constituiçáo Federal de 1988, como quilombolas, foram trazidos ao Brasil com escravos da África inicialmente para a plantaçâo de cana de açúcar, sem nenhum direito, sendo considerado meramente um objeto. A base inicial do direito no Brasil era um direito para donatários das terras de cunho privado em suas relaçôes e um embrionário direito administrativo para a administraçâo das Capitanias Hereditárias (1520-1549) pelos Governadores Gerais, cujos instrumentos jurídicos eram as Normas Eclesiásticas, Forais e as Cartas de Doaçâo. Posteriormente, foram impostas as Ordenaçóes Afonsinas (1446), as Ordenaçōes Manuelinas (1521) e as Ordenaçôes Filipinas (1603), eram as Ordenaçóes do Reino para cumprimento obrigatório no Brasil. E já no século XVIII, os Portugueses impuseram as "Leis da Boa Razăo" (1769) que eram regras sobre a aplicaçăo e interpretaçâo de leis no Brasil, buscando diminuir a influência do Direito Romano aplicável apenas subsidiariamente para a valorizaçăo das normas coloniais vigentes no Brasil (Op.cit. p. 48).

O modelo jurídico hegemônico no Brasil regulou a colonizaçăo que nas inferências de Césaire (1978, p. 25) é sinônimo de "coisificaçấo" consciente de seu caráter desumanizador, baseado no desprezo com os povos indígenas produz na relaçáo entre colonizador e colonizado: a força, a brutalidade, a crueldade, o trabalho forçado, a discriminaçăo, o choque, a tortura, ou seja, năo funda ou mantém nenhum direito humano.

Observa-se nos primeiros momentos de construçâo do Direito no Brasil uma relaçâo direta do Direito com o colonialismo diante da dominaçáo colonial Portuguesa, segundo reflete Wolkmer (2002, p. 49), instituindo um direito completamente alienígena para se beneficiar com a tributaçăo, um direito penal abrangente para reprimir as revoltas e garantir a classe dominante emergente um direito agrário concentrador e segregador da populaçăo nativa.

No Brasil e na América Latina o Direito dos povos indígenas com características informais e geralmente orais, foram marginalizados,eram considerados no máximo como costume (WOLKMER, 2002), sem qualquer valor jurídico, aqui já se pode notar a vinculaçăo do colonialismo com o racismo, segundo Quijano (2005, p.107) a expansâo do colonialismo pelo mundo desencadeou em uma perspectiva eurocêntrica do conhecimento e com esta à elaboraçăo de uma teoria de raça, como naturalizaçáo destas relaçôes coloniais de superioridade entre os dominantes e dominados.

Os povos conquistados e dominados foram postos em uma situaçăo jurídica, cultural, política de inferioridade e consequentemente também seus traços fenotípicos estigmatizados passando o dominante a inventar a autointitulaçăo de branco em antagonismo das identidades sociais novas: os negros, os índios e os mestiços(QUIJANO, 2005).

O colonialismo e a ideia de raça contrapuseram os conhecimentos dos grupos sociais locais violentados e subalternizados, no que Grosfoquel (2007, p.32) denomina de "racismo epistêmico" ou racismo epistemológico privilegiando e sobrepondo 
as políticas identitárias dos brancos ocidentais, sendo considerado como a única e legítima forma de produçấo do conhecimento capaz de elaborar teorias em que se separa o sujeito do objeto, defende o conhecimento neutro e "universal" capaz de se chegar à "verdade".

Partindo da teoria de Grosfoquel compreendo a existência no Brasil do que denomino de "racismo jurídico"que é uma espécie de racismo epistêmico, pois assim como este desconsidera os conhecimentos náo-ocidentais como inferiores aos conhecimentos ocidentais, o "racismo jurídico" considera as práticas jurídicas dos povos e comunidades tradicionais como mero costume ou práticas culturais sem valor jurídico, deixando de reconhecer no caso brasileiro as práticas orais e informais dos povos indígenas, comunidades quilombolas e outras comunidades tradicionais como Direito.

O Direito oficial vai produzindo mitos em que esconde o sujeito da enunciaçăo, ou seja, quem "fala" pelo Direito, que geralmente e hegemonicamente é um corpo político masculino e de acordo com as reflexóes de Castro-Gomez (2005, p.85) é o sujeito proprietário individual, casado, heterossexual, reacionário e defensor do modo de produçăo capitalista. Diferentemente, o direito produzido pelas práticas sociais e culturais dos povos e comunidades tradicionais quem o enuncia săo os próprios grupos sociais aviltados historicamente pelos processos violentos de colonizaçáo nâo apenas físico e cultural, mas também no sentido apontado por Fanon (1968, p.19) que os povos locais sâo considerados sem valores, em que suas tradiçôes e seus mitos sâo relegados à indigência e da depravaçâo.

Em outras palavras, os valores e as práticas jurídicas dos povos nâo sâo equiparáveis a Constituiçăo ou leis no sentido moderno, estăo para a organizaçăo jurídica do Estado Moderno abaixo disto, ou seja, estas identidades convertidas em reivindicaçōes territoriais tornam um problema para o direito moderno moldado năo pela diversidade sociocultural e sim pela regulaçâo via padrôes jurídicos universais.

Embora no Brasil e na América Latina em geral o colonialismo histórico-político nas Américas tenha sido extinto formando naçóes política e juridicamente independentes, principalmente nos séculos XIX e XX, este processo năo foi suficiente para a libertaçăo econômica, cultural e jurídica destes países da periferia do capitalismo, mantendo-se nestes países relaçóes de "colonialidade de poder" expressâo desenvolvida por Quijano $(1997 ; 2005)$ como um processo de manutençâo das estruturas jurídicas de poder ligadas organizaçấo do Estado, ao controle do trabalho, ao exercício da dominaçáo racial e de produçấo do conhecimento que transcende o processo de independência ou descolonizaçăo, a despeito da independência política dos Estados, a relaçăo colonial entre Estados centrais e periféricos se mantém.

Mignolo dialoga academicamente com Quijano e ajuda a articular este debate ao revelar que há uma relaçâo intrínseca entre colonialidade e modernidade. A colonialidade é constitutiva da modernidade, nâo pode haver modernidade sem colonialidade (2010, p. 46), pois esta é o lado obscuro da modernidade que é o modo de organizaçâo da vida social na Europa a partir do século XVII que foi transformado o mundo abaixo de sua influência (GIDDENS, 1993), esta organizaçâo só foi possível pela conquista da América. Nascia o sistema-mundo moderno com a criaçâo da América formando o sistema mundial de uma economia-mundo capitalista que nâo haveria sem as Américas. O capitalismo e a modernidade sâo um fenômeno europeu e năo planetário, isto é, a 
colonialidade do poder representa esta estrutura de controle do poder, que marca as diferenças coloniais, com os eixos de controle do trabalho na forma da empresa capitalista; controle da produçâo-apropriaçấo e distribuiçăo dos produtos articulados em torno da relaçấo capital-salário (MIGNOLO, 2005, p. 36).

A colonialidade/modernidade instaura o capitalismo como sistema econômico dominante seja o capitalismo liberal desorganizado do século XIX e XX, o capitalismo organizado do Estado-Providência no pós-guerra e o capitalismo desorganizado neoliberal do pós década de 70 do XX,náo cumpriram as promessas da Modernidade, especialmente as alvoradas do Constitucionalismo Liberal do século XIX de libertaçâo individual e coletiva, ou seja, de emancipaçâo do sujeito individual. O Direito Moderno consolidou-se como direito estatal diante da tensâo entre regulaçăo social e emancipaçâo prevalecendo à regulaçáo a serviço dos instrumentos de poder e manutençâo da ordem e da repressáo diante do caos provocado pelo capitalismo da Modernidade(SANTOS, 2002).

Os triunfos da ideologia liberal e a absolutizaçăo do direito oficial estatal como fonte totalitária do Direito provocam nos dizeres de Santos (2002) a separaçăo entre Estado e sociedade civil, sendo esta como objeto de regulaçâo do Estado.Assim, nos países do capitalismo periférico as normas estatais regulam as entidades da sociedade civil, como é o caso das associaçóes jurídicas, desconsiderando a existência de direitos e práticas socioculturais locais fora da idealizaçáo jurídica do Código Civil, que por seu conteúdo de caráter universal desconhece as formas próprias dos povos e comunidades tradicionais expressarem seus modos de organizaçăo social.

\section{RECONHECIMENTO DOS POVOS: ASSOCIAÇÕES DE "DIREITOS COLETIVOS" E AS ASSOCIAÇÕES DE DIREITO CIVIL}

A subordinaçăo dos povos indígenas e comunidades tradicionais as categorias jurídicas do Estado Brasileiro preexistentes ${ }^{5}$ (sujeito de direito, contrato e associaçóes) ao reconhecimento formal dos direitos dos povos e comunidades tradicionais pela Constituiçâao Federal de 1988 implica em uma relaçăo ambígua de reconhecimento/ desconhecimento da alteridade e da diversidade sociocultural brasileira.

Mesmo quando o Estado desloca sua atuaçăo de um colonialismo interno6, ou seja, do Estado conquistador para o Estado protetor, o mesmo nâo perde sua característica de Estado liberal impondo suas formas jurídicas aos povos e comunidades tradicionais como ocorre com a constituiçăo das "associaçôes" instituto de direito individual e privado exigido pelo Estado para enquadrar os povos e comunidades como "pessoas jurídicas

5 Compartilho a preocupaçăo de reconhecimento jurídico com categorias preexistentes com as reflexôes de Joaquim Shiraishi Neto e Fernando Antônio de Carvalho Dantas em artigo intitulado: "A "Commoditizaçāo" do Conhecimento Tradicional: notas sobre o processo de regulamentaçăo jurídica". Para os autores referindo-se a utilizaçâo das categorias "contrato" e "sujeito de direito" nas relaçóes jurídicas que envolvem a regulamentaçăo da apropriaçăo dos conhecimentos tradicionais tendem a desarticular as relaçóes construídas pelos povos e comunidades tradicionais ameaçando de forma contraditória a própria diversidade (SHIRAISHI NETO; DANTAS; 2008).

6 Ver conceito no primeiro tópico. Para um maior aprofundamento ver Cardoso de Oliveira, 1966 sobre a noçâo de "colonialismo interno". 
de direito privado" desconsiderando o significado destes institutos para os próprios sujeitos e os modos de organizaçâo política interna dos grupos sociais (COELHO; 2002; SHIRAISHI NETO; DANTAS; 2008).

O Estado brasileiro percorreu um longo caminho até o reconhecimento limitado ao multiculturalismo dos povos e comunidades tradicionais na Constituiçăo Federal de 1988, os povos indígenas foram afirmados apenas como "índios" com direito a posse permanente das áreas tradicionalmente ocupadas, direito este extremamente fragilizado pela exigência do Supremo Tribunal Federal do marco temporal7, ou seja, a presença dos povos indígenas na data da promulgaçăo da Constituiçăo Federal de 1988, como exigência temporal, esvazia a força normativa da Constituiçáo, além de outros direitos ${ }^{8}$. Além dos povos originários, foram reconhecidos expressamente no texto Constitucional: os quilombolas como "remanescentes de quilombos" e os seringueiros como grupos sujeitos a uma reparaçâo indenizatória histórica por sua utilizaçăo como "soldado da borracha".

No entanto, convém salientar o processo histórico de reconhecimento foi sofrível e violento. Ao longo do século XIX os "índios" eram vistos pelo Estado brasileiro, como uma ameaça a ser contida quanto como uma possibilidade de mâo-de-obra escrava a ser explorada. Assim, efetivaram-se os aldeamentos dos índios, as guerras "justas" para adestrá-los ao trabalho, porquanto havia duas classes de índios: os integrados, trabalhadores forçados ou mortos. Em outras palavras, quando năo eram invisíveis para os Estados Nacionais eram visíveis mortos ou escravizados. Os povos africanos trazidos como escravos eram objetos, coisas, quer dizer nem pessoas eram no processo histórico brasileiro e mesmo quando a Constituiçăo Imperial de 1824, reconheceu a liberdade como direito de todos manteve uma das exigências do início da Colonialidade/ Modernidade a escravidāo (MARÉS; 2015; COELHO; 2002).

No caso dos povos quilombolas, desde a libertaçâo dos escravos, em 1888, as normas jurídicas mantiveram-se silente em positivar algum direito a estes povos, a integraçâo dos povos quilombolas ao direito foi realizada pelo direito individual que năo impediu as manifestaçōes de racismo do Estado e da sociedade brasileira nos aspectos relacionados à exclusâo social, à favelizaçâo do negro, o racismo nas relaçôes interpessoais, desvalorizaçấo no trabalho e a desigualdade no mercado de trabalho, negros como foco das abordagens e da violência policial. Neste cenário, mascarando a realidade social foi construído o mito da democracia racial no Brasil expressado por Freyre (1933) na valorizaçăo da mestiçagem como mistura e complementariedade das três culturas: negro, branco e índio. Assim, por exemplo, de acordo com o mito, a racionalidade do colonizador compensaria a afetividade do índio e a sensualidade do negro (OLIVEIRA FILHO; 1999; MARÉS; 2015).

Passados 100 (cem) anos da "Lei Áurea" período marcado pela ausência de direitos coletivos aos povos quilombolas, com a promulgaçăo da Constituiçâo Federal de 1988, o quadro jurídico começou a se alterar com o reconhecimento constitucional

7 A jurisprudência do Supremo Tribunal Federal tem exigido o "marco temporal" para o reconhecimento das terras indígenas.(PET 3388; Ag. Reg. no Recurso Extraordinário com Agravo 803.462 Mato Grosso do Sul, "Caso limāo verde")

80 art. 231 da Constituiçáo Federal elencou uma série de direitos aos povos indígenas como o direito a organizaçấo social, línguas, costumes, tradiçōes e terras tradicionalmente ocupadas. 
das comunidades remanescentes de quilombos por força do artigo 68 do Ato das Disposiçôes Constitucionais Transitórias (ADCT) da Constituiçáo Federal de 1988 que preceitua: "aos remanescentes das comunidades de quilombos que estava ocupando suas terras é reconhecida a propriedade definitiva, devendo o Estado emitir-lhes os respectivos títulos".

A previsăo Constitucional do direito a titulaçăo năo deve ser interpretado como algo dado ou naturalizado decorrente do voluntarismo ou da filantropia do Constituinte. Pelo contrário, nâo se podem escamotear as reivindicaçôes do movimento negro durante o século XX, inicialmente com a Frente Negra Brasileira de 1930 e posterior mente com o Teatro Experimental Negro nas décadas de 1950-1960. Após o golpe militar de 1964, os quilombos representavam um núcleo de resistência ao autoritarismo. No início da década de 70, um grupo de militantes do movimento negro sediado em Porto Alegre criou o Grupo Palmares, elegendo em 20 de novembro como a data da morte do Zumbi como um dia a ser lembrado e o dia 13 de maio celebrado como a data oficial da celebraçấo da aboliçâo da escravidâo. No que concerne à luta pelo acesso dos povos negros a terra foi marcante a criaçăo nos Estados do Maranhâo e no Pará, as congregaçôes de comunidades negras rurais. Nesta época, foi criada a fundaçâo do Centro Cultural Negra do Maranháo (CCN) e do Centro de Estudos e Defesa do Negro no Pará (Cedenpa) (MELLO, 2012, p. 35).

O constituinte de 1988 ao utilizar o termo "remanescente" ligado a "sobras", "resíduos", talvez náo tivesse esperado tamanha mobilizaçăo por direitos territoriais e a força dos agentes sociais se constituindo em identidades coletivas organizadas em movimentos sociais (ALMEIDA, 2011, p.162). Dados oficiais apontam que existem no Brasil 743 (setecentas e quarenta e três) áreas de remanescente de quilombos, cuja populaçăo estaria estimada em 2 milhóes de habitantes distribuídos e 30 milhóes de hectares. No entanto, estimativas náo oficiais reportam a existência de $3 \mathrm{mil}$ comunidades, sendo que em 23 anos apenas 90 áreas foram tituladas (ALMEIDA, 2011, p. 163).

A titulaçâo é coletiva em nome da Associaçăo e condicionada ao seu controle, ou seja, tornando as terras, segundo Almeida (2011, p.161) um obstáculo às tentativas de disponibilizá-las ao mercado de terras para venda tornando-a imobilizada ${ }^{9}$. Neste ponto, problematizamos as possíveis implicaçôes desta obrigatoriedade.

A organizaçâo dos povos quilombolas em associaçôes relaciona-se com um movimento mais amplo analisado por Hobsbawn (1995, p.406) diante da constataçăo do enfraquecimento dos Sindicatos pela atuaçăo das empresas transnacionais que dominam a economia mundial vários cidadăos deixaram de militar em Sindicatos e partidos políticos de esquerda para atuarem em movimentos sociais mais específicos como os que atuam na defesa do meio ambiente de acordo com sua atividade, como é o caso dos seringueiros, na preservaçăo dos seringais, das quebradeiras de coco na proteçâo

9 Os antropólogos Alfredo Wagner de Almeida e Rosa Acevedo Marin (2008, p.141) demonstram preocupaçâo com as agro-estratégias que săo medidas de interesse do agronegócio para remover os obstáculos jurídico formais que impedem as novas extensôes de terras para o mercado. (ALMEIDA; MARIN. Campanhas de desterritorializaçâo na Amazônia: o agronegócio e a reestruturaçáo do mercado de terras. In Amazônia Regiâo universal e teatro do mundo. Willi Bolle, Edna Castro e Marcel Vejmelka (org.).Editora Globo, 2008. 
das palmeiras, movimentos feministas e de identidade étnica deslocando a ênfase de atuaçăo de políticas universais para políticas específicas do grupo social.

Os movimentos sociais do campo foram saindo do controle dos Sindicatos dos Trabalhadores e Trabalhadoras Rurais e passaram a organizar associaçóes principalmente especialmente a partir de 1988-1989,que escapam o sentido da luta de uma entidade sindical, por serem associaçōes específicas incorporaram fatores étnicos, ecológicos, ambientais e critérios de gênero e autodefiniçấo coletiva com objetivo de modificar os critérios das açōes político-administrativas do Estado marcadas por uma burocratizaçâo excessiva e etnocentrismo construindo o Estado um "saber prático" sobre os direitos dos povos tradicionais mais reforçando o positivismo diluindo os fatores étnicos na noçấo de povo fundamental para homogeneizaçăo dos povos (ALMEIDA, 2004; 2011).

As associaçôes que aqui denomino de "direitos coletivos" com caráter étnico, cultural, político e social,atuam perante os poderes públicos ressaltando os fundamentos étnicos e de proteçâo da natureza na reivindicaçâo de seus territórios tradicionais e demais direitos correlatos. $O$ direito para se tornar democrático e efetivamente descolonizar-se deve incorporar os esforços teóricos frutos da interlocuçăo direta com os povos e comunidades tradicionais dialogando com a antropologia e ao contrário do formalismo jurídico contestado por Bourdieu (2007, p. 106) que afirma a autonomia absoluta do direito em relaçáo ao mundo social, o direito segundo Chagas (2011, p. 262) nâo deve se divorciar da participaçâo dos "atores jurídicos, sociais e políticos", acrescentamos "atores étnicos" para o fortalecimento da força normativa da Constituiçấo da República de 1988e neste sentido compartilhamos com o entendimento de Duprat (2007, p. 9)que o Estado brasileiro deveria se consolidar como pluriétnico e multicultural pelo texto Constitucional.

Em torno da criaçâo das associaçōes pelos povos e comunidades tradicionais há uma disputa sobre o reconhecimento do Estado brasileiro como pluriétnico, pois estas associaçōes năo se limitam a temas comuns de acordo com os ditames dos dogmas jurídicos rígidos sobre associaçóes como a "uniâo de pessoas para fins năo econômicos" para fins culturais, sociais e ambientais. As incorporaçōes de fatores étnicos e do forte cunho político das associaçōes retiram-na de seu lugar tranquilo, pois a dogmática sobre associaçôes ao conceituar sua finalidade năo imagina esta possibilidade, visto que a dogmática jurídica convencional distancia-se dos debates em torno do direito étnico e do reconhecimento do Estado Pluriétnico, ou seja, como nos lembra Leivas (2006) este debate sobre "associaçôes de direito coletivo étnico" nos ajudam a superar os limites impostos pelo positivismo jurídico no amplo campo dos direitos fundamentais.

As associaçôes de "direito coletivo" estăo ligadas à ideia de identidades múltiplas (Canotilho, 2001) săo entidades fundamentais para a titulaçăo das terras dos grupos quilombolas. Compreendo a diferença das "associaçóes étnicas de direito coletivo" fazendo com que haja "relativizaçâo das categorias jurídicas", como afirma Shiraishi Neto (2014, p. 11) categorias que săo tomadas como "naturais" e universais fazendo com que situaçóes dos povos e comunidades tradicionais contemporâneas sejam vinculadas a esquemas jurídicos preexistentes.

As associaçōes de "direito coletivo" nâo săo juridicamente as mesmas do Código Civil e năo podem ser interpretadas tăo somente sob este regime jurídico, pois estăo 
protegidas pelo arcabouço jurídico da Constituiçăo Federal de 1988, que institui no art. 215 e 216, como patrimônio cultural brasileiro os bens de natureza material e imaterial como referência à identidade, à açâo dos diferentes grupos formadores da diversidade brasileira, incluindo o respeito as formas de expressăo, criar e viver e preservar os espaços destinados às manifestaçōes culturais, artísticas e políticas, como é o caso das associaçōes dos povos e comunidades tradicionais.

Deste modo, faz-se necessário um estudo empírico sobre as associaçōes instituídas pelos povos e comunidades tradicionais, os quais demonstram as diferenças concretas entre as associaçōes de direito coletivo étnico e as associaçōes ortodoxas previstas abstratamente pelo Código Civil Brasileiro. Optamos por maior contato de pesquisa, pelas quebradeiras de coco babaçu da regiăo do Médio-Mearim do Maranhăo e os piaçabeiros do médio Rio Negro do Estado do Amazonas.

\section{AS QUEBRADEIRAS DE COCO BABAÇU E A EXPERIÊNCIA COM AS ASSOCIAÇÕES}

Para o desenvolvimento deste tópico utilizamos pesquisa teórica e dados colhidos na pesquisa de campo com as quebradeiras de coco babaçu e suas organizaçôes sociais registradas na forma de "Associaçôes Civis", pesquisa esta realizada entre 28 de abril e 02 de maio de 2010 e de 08.02.2011 a 03.03.2011; 28.03.2011 a 08.04.2011, nos municípios maranhenses de Săo Luís, Pedreiras, Esperantinópolis e Lago do Junco. A pesquisa de campo teve como objetivo de obtençâo de dados empíricos para a dissertaçấo de Mestrado intitulada "As quebradeiras de coco babaçu e o mercado: Dilemas entre proteçâo dos conhecimentos tradicionais e a sujeiçăo jurídica".Também utilizaremos pesquisa de campo e bibliográfica realizada por outros pesquisadores sobre o tema.

As quebradeiras de coco babaçu como já foi destacado na introduçâo deste artigo săo um grupo de mulheres trabalhadoras rurais e agroextrativistas oriundas de um campesinato formado por descendentes de povos indígenas destribalizados, negros escravizados e nordestinos deslocados de regióes mais ao leste do Nordeste para o Maranhăo, formando comunidades quilombolas no Maranhăo no século XIX e início do século XX, que vieram como migrantes nordestinos "retirantes da seca". As quebradeiras aliam a quebra do coco babaçu com o trabalho na roça. Estăo presentes em 04 (quatro) Estados brasileiros: Maranhâo, Pará, Piauí e Tocantins (BARBOSA, 2006, p. 36; PORRO, 2002, p.11; ANTUNES, 2006, p. 123).

As quebradeiras de coco babaçu enfrentam históricos conflitos pela preservaçâo dos babaçuais,que incidem nas fazendas de propriedade privada, pelo acesso ao coco babaçu, mesmo nos casos de "coco preso" que sâo aqueles que incidem em áreas de propriedade privada, em razăo da relevância jurídica do fator histórico de que as atividades agroextrativistas das quebradeiras de coco babaçu săo preexistentes aos cercamentos privados das fazendas cujo poder de fruir, usar e dispor da terra privada ao fazendeiro teve amplo apoio Governamental, com a outorga em 1969 da Lei n. ${ }^{\circ} 2.979$, conhecida como Lei de Terras do Governo Sarney, tal norma segundo Gonçalves (2000, p. 29) foi à propulsora dos incentivos a grandes empreendimentos, gerando a concentraçâo de terras no Estado. Antes desta Lei, observou Agostinho (2010, p.52) estava em vigor no Maranhăo a Lei n. ${ }^{\circ} 439$ de 1906, norma que regulamentou as açôes do Estado, com 
vistas a dar uma aparente regularidade ao uso por particulares das"terras devolutas", concedendo títulos de propriedade a grandes faixas de terras, beneficiando aos grupos de fazendeiros no Estado do Maranhăo e na regiâo do médio Mearim, área de ampla incidência das palmeiras do babaçu. ${ }^{10}$

Os conflitos atuais com os fazendeiros e grandes indústrias de celulose, ferro e gusa, carvoarias na regiăo, ocorrem pela posiçăo antagônica das quebradeiras de coco babaçu em relaçâo aos demais agentes sociais na regiăo, os "antagonistas", que săo empresários e fazendeiros em permanente conflito com as quebradeiras de coco babaçu devido a atuaçâo das mesmas na luta pela preservaçăo dos recursos naturais, reivindicaçôes de acesso a terra e regularizaçăo fundiária para a realizaçăo do trabalho na roça, coleta, quebra do coco e organizaçăo da produçăo, bem como uma reivindicaçáo convertida em Lei denominadas "Leis do Babaçu Livre", que sâo as lutas pelo livre acesso ao coco babaçu mesmo que estejam em áreas sob o domínio privado.

A microrregiâo do Médio Mearim local da pesquisa de campo deste autor foi marcada entre as décadas de 1970 e 1980, por intensos conflitos entre trabalhadores rurais e fazendeiros ou grileiro, quando estes passaram a proibir a extraçăo do coco babaçu, com base no direito de propriedade, o que desencadeou forte resistência pelas quebradeiras de coco e seus maridos. Este é o contexto histórico da necessidade das quebradeiras criarem um movimento e institucionalizarem juridicamente como uma "Associação".

A valorizaçâo das quebradeiras de coco, enquanto grupo, pelos poderes constituídos foram ocorrendo, segundo Almeida (1995, p. 34), a partir de 1988 e 1989 com o processo de mobilizaçăo intensa dos trabalhadores rurais em torno da criaçăo de iniciativas de associativismo e cooperativismo. Esse reconhecimento extrapolou o âmbito local, com a criaçăo do MIQCB - Movimento Interestadual das Quebradeiras de Coco Babaçu em 1991.

\subsection{O MIQCB - MOVIMENTO INTERESTADUAL DAS QUEBRADEIRAS DE COCO BABAÇU PARA ALÉM DE UMA ASSOCIAÇĀO CIVIL}

O MIQCB é um movimento social que foi criado em 1991 e que tem por escopo mobilizar e organizar as Quebradeiras de Coco Babaçu no afă de conseguir a valorizaçâo econômica, política e social do papel das mulheres nas sociedades locais e gerais, cujo objetivo é organizar as quebradeiras de coco para conhecerem seus direitos, na defesa das palmeiras de babaçu, do meio ambiente e da melhoria das condiçóes de vida e de trabalho nas áreas de ocorrência dos babaçuais.(MACIEL, 2012, p. 57)

Embora tenha sido formalizado como Associaçâo Civil é um movimento social com características muito mais amplas daquilo que a dogmática do direito prevê para as "Associaçôes" com direitos e obrigaçóes destinadas ao sujeito de direito que tem a

10 Em entrevista no documentário "Bora Gente: Diálogos em movimento" a Dona Alaídes falou sobre a "guerra" armada promovida contra as quebradeiras de coco babaçu para através da violência e assassinatos impedir o acesso das quebradeiras e seus familiares à terra, fazendo com que seus maridos tivessem que permanecer acordados no "mato" vigiando se nâo vinha a polícia ou os capangas dos fazendeiros para expulsar as quebradeiras de coco babaçu, pois nâo detinham o título de propriedade da terra concedido pelos Governo por meio das normas jurídicas mencionadas no texto. 
vontade como base de associarem-se ou permanecerem associados. Neste caso, a pesquisa empírica demonstra que o movimento social e interestadual antecedeu a forma jurídica de associaçấo que foi apenas a exteriorizaçăo jurídica decorrente de um amplo movimento de assunçăo de identidades de quebradeiras de coco babaçu. Em outras palavras, o elemento de assumir identidade náo é à vontade, mas a identidade coletiva e a autoconsciência cultural de pertencimento a um grupo social.

A forma jurídica de "Associaçóes" tende a absorver a identidade do indivíduo e do grupo que o forma, quer dizer, pelo que foi constatado nas entrevistas, pouco importa para as quebradeiras a condiçấo formal de "associadas", o que tem valor preponderante é o pertencimento ao "Movimento" das quebradeiras de coco babaçu. Sobre o tema observou Oliveira (1979) em seu estudo sobre a "Dupla Crise da Pessoa Jurídica" ressaltando um vício de origem na teoria da pessoa jurídica que é negar a existência de grupos intermediários entre o Estado e indivíduos. É como se as associaçôes para o direito fossem formadas por um agrupamento de indivíduos com objetivos comuns e passam a ser "pessoa jurídica", ou seja, sujeitos de relaçōes jurídicas junto ao Estado, as demais pessoas jurídicas e indivíduos.

A Presidente do MIQCB, a época Dona Dijé, em entrevista afirmou que o movimento o movimento visa o fortalecimento político nâo apenas das sócias da entidade, mas a luta é mais ampla e abrange a todas as quebradeiras de coco babaçu Relatou a entrevistada:

A luta das Quebradeiras de Coco é pelo reconhecimento dos direitos relativos ao conhecimento oriundo da experiência, sua organizaçăo político-social para dizer aos Governos que o Babaçu faz parte da sobrevivência das Quebradeiras. O babaçu é a principal bandeira de luta do movimento, para que năo tenham que sair do campo. O MIQCB requer o reconhecimento das Quebradeiras como cidadăs e espera que a academia seja cada vez mais sensível às causas das Quebradeiras." (Entrevista sede do MIQCB, Săo Luís 08 de fevereiro de 2011.)

Nota-se a abrangência do movimento que ao obter benefícios como a aprovaçăo de Leis, nâo beneficia apenas as sócias da Associaçấo, mas a todas as autoidentificadas como quebradeiras de coco babaçu.

Observa-se que o Movimento Interestadual das quebradeiras de coco babaçu concentrado em quatro Estados da Federaçáo, com sede em Sáo Luís, movimenta a luta por direitos em termos nacionais e náo apenas locais, possui seis regionais: do Mearim, de Imperatriz e da Baixada (as três no Maranháo), do Pará, do Piauí e do Tocantins. Cada uma possui coordenaçăo executiva e assessoria técnica, apoiada por projetos de diversas ONG's e com a Uniăo Europeia (BARBOSA, 2006, p. 36).

Observou Maciel (2012, p. 59) que o Movimento Interestadual das quebradeiras de coco babaçu promove periodicamente encontros interestaduais para discutir questóes relacionadas à preservaçâo das palmeiras babaçu, livre acesso ao coco babaçu, questóes de gênero, educaçăo no campo, acesso à terra, conhecimentos tradicionais e trabalho infantil, entre outros. Estes encontros têm sido fundamental para a integraçâo do grupo, para sua reafirmaçâo étnica e proposiçâo de seus próprios direitos específicos. Acarretou no fortalecimento do movimento no campo político de atuaçấo, dentro de uma sociedade que tem por fundamento constitucional o pluralismo, positivado na Constituiçấo Federal de 1988. 


\subsection{A ASSOCIAÇĂO EM ÁREAS DE ASSENTAMENTO DO ESTADO DO MARANHÄO - ASSEMA}

No município de Pedreiras, Estado do Maranhăo foi realizada pesquisa de campo na Associaçâo em Áreas de Assentamento no Estado do Maranhâo - ASSEMA. A entidade foi fundada em 1989, por lideranças locais do município de Esperantinópolis, Estado do Maranhâo, articuladas com as de Lago do Junco, Săo Luiz Gonzaga e Lima Campos ${ }^{11}$.

A ASSEMA constitui uma entidade social liderada por trabalhadores rurais, homens e mulheres voltados a prestar assessoria técnica, social, jurídica, econômica e política, aos homens do campo e às quebradeiras de coco babaçu em suas açóes em melhoria da qualidade da agricultura familiar, estimulando a organizaçăo em sistemas associativistas e cooperativistas ${ }^{12}$. Em outras palavras, pelo que se verificou na pesquisa junto ao sitio da ASSEMA, em nenhum momento em seu conceito institucional consta a palavra "Associaçăo" a năo ser em seu nome por força de lei, mas consta como uma "entidade social" liderada por trabalhadores rurais. Ou seja, a forma jurídica imposta pela lei é relegada a um plano secundário diante das amplas finalidades da entidade. Neste sentido, revelou o técnico Ronaldo Carneiro de Souza, militante nos movimentos sociais desde 1988, trabalha na ASSEMA desde 1998, relatou sobre a entidade que:

ASSEMA para ser fundada teve que fazer um desafio, trabalhar a assessoria técnica na regiáo, organizaçăo sociopolítica, criar associaçóes, lutar por terras e a questăo ambiental. Ela passou por um período de avaliaçăo em 1995 e 1996 e em 1997 passou a trabalhar com agricultura mais limpa, pensando na preservaçăo do babaçu. (RONALDO CARNEIRO DE SOUZA, Entrevista realizada em Pedreiras. Em 10.02.2011)

Observou-se no trecho acima, a tripla preocupaçáo da entidade com assistência técnica, com a organizaçâo social dos grupos e com a preservaçăo ambiental.

O entrevistado afirmou que a ASSEMA trabalha em rede com outros movimentos sociais, que articulados, passaram a colocar em pauta a questăo ambiental ${ }^{13}$, visando trabalhar com uma agricultura mais limpa, sem agrotóxicos e voltado para a preservaçăo dos babaçuais.

Além do fomento e apoio técnico à questăo agroextrativista, a associaçăo comercializa produtos manufaturados e transformados a partir do manejo do babaçu, registrando nos produtos a marca "Babaçu Livre", o que denota uma tentativa de politizaçâo do mercado para que setores sociais e empresariais também passem a divulgar a ideia de que năo pode existir limitaçăo privada ao acesso das quebradeiras de coco às palmeiras de babaçu, pois é do recurso natural que se garante a reproduçâo física e social do grupo.

11 PORRO, Noemi Miyasaka; VEIGA, Iran. Caderno de Estudos: A experiência da COOPAESP, ASSEMA e MIQCB com a medida provisória 2186-16 de 2001. Esse Caderno de Estudos versa sobre a experiência da COOPAESP, ASSEMA e MIQCB na relaçáo com a empresa Natura, na perspectiva das lideranças, colaboradores e assessorias.

12 ASSOCIAÇĀO EM ÁREAS DE ASSENTAMENTO DO ESTADO DO MARANHÂO - ASSEMA. Quem somos? Disponível em http://www.assema.org.br/geral.php?id=Quemsomos. Acesso em: 20.04.2011.

13 O entrevistado relatou que o discurso de proteçáo ambiental do movimento serviu para justificar o acesso e a luta pela terra e a reivindicaçâo em relaçăo à Lei do Babaçu Livre. 
Nesta parte, verifica-se que o regime jurídico "Associaçáo" pode limitar as atividades da ASSEMA diante da previsâo do Código Civil de "fins năo econômicos" das Associaçôes. No entanto, a finalidade da ASSEMA năo é econômica, pois nâo possui intuito de "lucro", mas de traduzir uma política de estímulo a marca "babaçu livre", sendo esta atividade meramente de subsistência da entidade que possui finalidades amplas.

Segundo o documento obtido junto à entidade denominado de "Apresentaçâo Institucional 2008", a ASSEMA visa à consecuçăo de diversas estratégias de sustentabilidade política e financeira com a busca por novos apoiadores e por mercado para os produtos "Babaçu Livre" ${ }^{14}$ e atuaçāo da entidade junto as famílias agroextrativistas e organizaçóes associadas em áreas voltadas para educaçăo no campo, segurança alimentar das referidas famílias, esclarecimento em relaçăo a legislaçấo de acesso à biodiversidade e repartiçâo de benefícios, e atuação política para a formaçăo de economia solidária junto às cooperativas.

Sobre o tema repartiçâo de benefícios oriundos do acesso aos conhecimentos tradicionais das quebradeiras de coco babaçu decorrente do contrato de acesso aos conhecimentos tradicionais das quebradeiras de coco babaçu pela empresa Natura ${ }^{15}$, o entendimento das associaçóes ligadas em rede de atuaçăo conjunta seja a MIQCB e a ASSEMA possuem o entendimento de que o conhecimento tradicional pertence a todas as quebradeiras do Brasil, năo é de propriedade das Associaçōes, em geral os bens das associaçóes pertencem táo somente aos associados, observa-se que nas associaçóes aqui estudadas a dinâmica jurídica ligada à luta política é outra. Ou seja, ainda que a quebradeira de coco babaçu nâo seja associada das associaçóes terá direito à repartiçăo de benefícios pelo seu vínculo de identidade e de atividade junto ao movimento social.

Na pesquisa de campo foi convergente na fala dos técnicos e no documento apresentado pela ASSEMA denominado "Destaques no Trabalho da Assema 2008" que a repartiçâo de benefícios nâo poderia estar concentrada em um grupo de quebradeiras ou uma entidade social apenas.

No caso das "Associaçōes" convencionais a norma jurídica e a dogmática jurídica prevê o vínculo jurídico com a associaçăo pela forma jurídica de "estar associado", ou seja, é a relaçăo jurídica com a associaçăo que permite ao associado gozar dos benefícios da associaçăo, partindo de uma ideia individual de usufruir direitos. Diferentemente, a pesquisa com as quebradeiras de coco babaçu aponta que os direitos săo garantidos náo por ser a quebradeira de coco babaçu, sócia da associaçáo, mas simplesmente pelo vínculo de identidade étnica e de atividade com o conhecimento de quebrar o coco, fazer

14 Os produtos "babaçu livre" săo os produtos produzidos pelas quebradeiras de coco e fornecidos pela ASSEMA, como o sabonete com a marca "babaçu livre", o licor, o perfume e o sabáo.

15 Em 2005, a Natura entrou em contato com as entidades sociais representativas das quebradeiras de coco, babaçu com intuito de enviar dois profissionais para visitar a COOPAESP e a ASSEMA (Associaçáo em Áreas de Assentamento no Estado do Maranhăo), em razăo de ter pesquisado amostras de farinha de mesocarpo e chegado a resultados de interesse comercial, tendo o objetivo de lançar um cosmético contendo esse recurso da biodiversidade. Naquela oportunidade, a Natura informou à COOPAESP que existia a Medida Provisória n. ${ }^{\circ}$ 2.186-16, de 23 de agosto de 2001, garantindo novos direitos às comunidades tradicionais e que a Natura necessitava se regularizar em respeito a esses direitos, em virtude de já ter acessado amostras da farinha do mesocarpo. Assim, mediante a tentativa de regularizarse a empresa, após intensas negociaçōes, estabeleceu-se o vínculo jurídico com a comunidade tradicional, mediante a assinatura de um Contrato de Repartiçáo de Benefícios devido ao acesso aos conhecimentos tradicionais associados das quebradeiras de coco babaçu. 
o óleo, o sabonete, o licor e demais derivados do coco babaçu, ou, simplesmente por auto intitular-se quebradeira de coco babaçu e ser reconhecida como tal. Entender de modo estritamente civilista poderia levar a exclusăo das quebradeiras de coco babaçu năo associadas, que vivem em locais de maior difícil acesso, que ainda năo participam do movimento ou das associaçōes seja por questóes geográficas, econômicas, políticas, familiares ou por escolha pessoal.

\section{PIAÇABEIROS, INDÍGENAS E PESCADORES NO MÉDIO RIO NEGRO: ASSOCIAÇÕES NA DISPUTA POR TERRITÓRIOS}

No município de Barcelos ${ }^{16}$, na regiăo do médio Rio Negro, estado do Amazonas formaram-se diversas associaçóes em torno da extraçăo da piaçaba. Nesta regiâo atuam conflituosamente(embora haja alianças e acordos para objetivos comuns)os piaçabeiros, pescadores, os povos indígenas (Tariano, Tukano, Baniwa, Baré, entre outras), os empresários do turismo, e os "patrōes" que săo os comerciantes das fibras da piaçaba que intermedeia a relaçăo entre a produçăo local e a comercializaçăo externa. Estes "patróes" exploram a força de trabalho dos piaçabeiros pelo antigo sistema de "aviamento"17 (MENESES, 2013). Neste cenário, a pesquisa de campo de Elieyd Sousa de Meneses realizada em sua dissertaçáo de mestrado denominada "Os piaçabeiros no médio rio Negro: identidade étnica e conflitos territoriais" ajuda a entendermos as relaçóes jurídicas em torno da ideia de criaçăo de Associaçōes.

A complexidade das relaçôes sociais em torno da ideia de constituir "Associaçăo Jurídica" nos permitiu constatar que a compreensăo dogmática das "associaçôes" como um "objeto puramente cultural, beneficente, altruísta, religioso, esportivo ou moral", como conceituou Duarte (2015), năo se coaduna com a realidade fático-jurídica da diversidade sociocultural no Brasil. A constataçâo empírica vislumbrada pelo trabalho de Meneses (2013) pode-se constatar que nas relaçôes sociais compostas pelos piaçabeiros, "patróes" e pescadores as associaçôes têm por objetivo a conquista dos territórios coletivos como no caso dos piaçabeiros ou privados como no caso dos "patróes", ou seja, as associaçóes visam a conquista de diversas formas de territórios a depender do grupo social que constitui a associaçăo.

Os autodenominados piaçabeiros objetivam a criaçăo das associaçōes para a garantia do direito ao território para práticas extrativistas, ou seja, para o corte sustentável que os piaçabeiros praticam de modo a permitir a recuperaçâo das palmeiras de piaçaba em um período de três a quatro anos. Durante este período buscam novos territórios para terem acesso ao recurso natural e estabelecerem novos piaçabais, instituindo outras relaçóes de trabalho em outros lugares.

16 Informa Reis (2007, p.128) em sua pesquisa de mestrado que Barcelos é um dos 62 municípios do estado do Amazonas, com uma extensăo territorial de $122.476 \mathrm{~km} 2$, localizado no rio Negro distante da capital cerca de $496 \mathrm{~km}$ por via fluvial e $396 \mathrm{~km}$ em linha reta, sendo considerado o maior município do Amazonas e o segundo do Brasil.

17 O aviamento segundo Meneses (2013) é o sistema de trocas fundamentado no adiantamento de mercadorias a crédito, caracterizando uma relaçáo vertical entre os agentes sociais eu o compóe, designados de patrōes e "fregueses". 
Os "patrôes" e suas "Associaçôes Civis" exigem a manutençăo e ampliaçâo de seus domínios privados do território para comercializar a piaçaba e buscam o reconhecimento em Associaçôes como "trabalhadores do ramo da piaçaba" e de controladores dos recursos naturais, sendo conhecidos como os "donos" dos igarapés, onde os piaçabeiros realizam suas atividades.

As associaçóes coletivas dos povos indígenas buscam a demarcaçăo dos seus territórios indígenas atraindo a oposiçâo dos pescadores que entendem que os rios serâo fechados e dos "patrōes", pois com a demarcaçâo a terra ficará indisponível para o mercado (MENESES, 2013, p. 19).

Os conflitos sociais marcados juridicamente pela criaçăo de "Associaçôes Civis" envolvem a luta por um "território em disputa" por diversos grupos sociais e por atores privados como os próprios "patróes", os madeireiros e os pescadores, grupos sociais que lançaram a campanha contra a demarcaçáo das terras indígenas. Ao observar a realidade e sua pesquisa de campo, constatou Meneses (2013, p. 30):

Ao interpretar a realidade empiricamente observável em Barcelos, noto que os agentes sociais estăo primeiramente reinvindicando "reconhecimento" e suas identidades coletivas - como piaçabeiros, indígenas, "patrōezinhos", pescadores - para só depois reivindicarem o acesso aos recursos naturais e ao território, e posteriormente à captaçấo de renda entre os grupos sociais.

Estes diversos agentes sociais na luta pelo "reconhecimento jurídico" de seus territórios interagem no sentido das fronteiras étnicas de Barth (2000, p. 2) em que os sistemas sociais săo interdependentes cujas diferenças culturais permanecem apesar do contato interétnico e das interaçôes sociais, culturais e políticas dos diversos grupos sociais que compōem esta complexa disputa pelo mesmo território.

As interaçóes e confluências interétnicas pode ser percebida pela aliança política entre piaçabeiros e povos indígenas, passando a existir indígenas-piaçabeiros e piaçabeiros-indígenas denotando os deslocamentos das identidades. Neste contexto, informa Meneses (2013) foi criada em 1999 a Associaçăo Indígena de Barcelos (ASIBA) como uma organizaçăo associativa heterogênea que reúne as etnias Tariano, Tukano, Baniwa, Arapaço, Wereuena, Tuyuca, também participam da Associaçăo como associados os piaçabeiros, castanheiros, pescadores, rezadores ou "benzedeiros". Informa Meneses (2013, p. 33) esta associaçáo tem por objetivo o fortalecimento da identidade étnica e dos modos culturalmente diferenciados e tradicionais dos povos indígenas de Barcelos. Na relaçáo com o Estado a principal reivindicaçăo além do reconhecimento étnico é a demarcaçăo de terras nos rios Caurés, Quiuini, Aracá, Demeni, Preto e Padaurinhos, nos municípios de Barcelos e Santa Isabel do Rio Negro.

A Associaçăo (Asiba) possui um forte sentido de consolidaçâo da identidade étnica frente ao Estado e demais grupos sociais, ainda que os associados năo pertençam a apenas uma etnia, visam o reconhecimento do Estado de suas açôes e lutas pelo território. Esta associaçăo tem uma finalidade étnica, cultural e política e tem enfrentado conflito com outras associaçōes como a Associaçâo Colônia de Pescadors Z-33, associaçáo que reúne 868 associados e congrega pescadores de peixe ornamental e pesca artesanal. É uma associaçăo que disputa de território e por acesso aos recursos naturais é intensa, inclusive os conflitos pelo acesso aos rios e sua manutençăo em zonas nâo demarcáveis, pois além da atividade pesqueira está em jogo a disputa sobre a área de incidência de piaçaba em Barcelos. 


\section{CONSIDERAÇÕES FINAIS}

A discussăo deste artigo teve como aspecto central discutir a necessidade de diferenciaçâo das Associaçôes de Direito Civil das Associaçōes de Direito Coletivo Étnicos, tendo como plano de fundo o questionamento sobre a obrigatoriedade dos povos e comunidades tradicionais organizarem-se juridicamente para garantia de direitos em relaçăo ao Estado ou entidades privadas.

A tentativa de enquadrar as associaçôes ligadas aos povos e comunidades tradicionais a uma exegese estritamente de Direito Civil, no entender deste artigo é uma forma de manutençăo dos processos de colonizaçăo e imposiçôes epistêmicas e de racismo jurídico diante do histórico năo reconhecimento do Estado brasileiro das formas orais de expressōes jurídicas e culturais dos povos indígenas e demais povos.

Entendo que estaimposiçâojurídica, se nâo reconhecido o seu caráter Constitucional de "Direito coletivo étnico" e a adoçáo de uma análise dialogada do Direito com os povos, pode significar a deterioraçăo das formas tradicionais no sentido exposto por Fanon (1968) em sua obra "Os condenados da terra". Em outras palavras, tentar aplicar ou interpretar tăo somente o Direito Civil privatista nos conflitos que envolvam as Associaçôes de caráter étnicotende a reforçar a desarticulaçăo das formas de organizaçăo jurídica específica dos povos indígenas e comunidades tradicionais.

No entanto, no Brasil atuaram diversos movimentos sociais em busca de reconhecimento de seus direitos territoriais, culturais e ambientais, estes movimentos foram mais amplos do que a constituiçâo e organizaçăo jurídica das associaçôes destes grupos, ou seja, primeiro houve o fortalecimento das mobilizaçōes sociais denominadas por Almeida (2007) de "unidades de mobilizaçâo" e os grupos ao perceberem que constituindo associaçôes poderiam dialogar melhor com o Estado, garantir maior acesso à Justiça e lutar juridicamente por direitos coletivos tiveram a sensibilidade de criar associaçōes civis.

Entretanto, as associaçôes civis criadas pelos povos e comunidades tradicionais na reivindicaçâo de direitos coletivos específicos nâo possuem as mesmas finalidades do modelo previsto pelo código civil e pelo direito civil como "agrupamento de indivíduos" vinculados a liberdade de associarem-se ou permanecerem associados, sáo associaçóes de direito étnico outro tipo de associaçấo na qual a busca de reconhecimento das diferenças étnicas é fundamental na luta por direitos territoriais dos povos indígenas na demarcaçâo de suas terras, dos povos quilombolas na titulaçâo de propriedade coletiva de suas terras, dos piaçabeiros para livrarem-se do sistema opressor do "aviamento" e em busca da preservaçăo e acesso a piaçaba e das quebradeiras de coco babaçu cuja identidade e a autoconsciência cultural firmam o propósito de associarem-se para fins ambientais, de relativizaçăo da propriedade privada com o acesso ao coco babaçu fechado nas fazendas, com objetivos de fortalecimento da identidade de gênero e pelas leis do "babaçu livre".

O desafio para o reconhecimento das "Associaçōes de direito coletivo" com caráter étnico, cultural, político e social, termo criado pelo autor,visa reconhecer que estas entidades ultrapassam os limites do reconhecimento individual do Estado liberal de separaçăo entre Estado e sociedade civil, e apartamento do homem com a natureza, pois as associaçôes dos grupos sociais nâo se amoldam a previsăo civilista de que os direitos serâo gozados apenas pelos associados, pois a identidade étnica se sobrepóe ao 
formalismo jurídico, haja vista a experiência das quebradeiras de coco babaçu em tentar garantir direitos para as quebradeiras náo associadas, através das açôes do MIQCB e da ASSEMA. A identidade antecede a associabilidade e a formalizaçáo dos associados enquanto membros da associaçăo.

Descolonizar o reconhecimento das associaçôes seria interpretá-las nâo de forma homogênea e universal como prevê o Código Civil para as associaçóes de indivíduos, mas compreender a dinâmica deste processo que envolve a abrangência dos direitos étnicos movidos pela amplitude dos movimentos sociais que săo dinâmicos e atuam em rede de organizaçóes sociais com alianças entre grupos, como a experiência das alianças entre indígenas e piaçabeiros em Barcelos e conflitos pelo território como ocorre com a Asiba e a Associaçăo dos Pescadores de Barcelos. 


\section{REFERÊNCIAS BIBLIOGRÁFICAS}

AGOSTINHO, Luane Lemos Felício. AS LEIS DO BABAÇU LIVRE: uma análise do processo de juridicizaçăo das práticas sociais das mulheres quebradeiras de coco babaçu. Dissertaçâo apresentada a Universidade do Estado do Amazonas. Programa de PósGraduaçăo em Direito Ambiental. Manaus, 2010.

ALMEIDA, Alfredo Wagner Berno de. Quebradeiras de Coco Babaçu: identidade e mobilizaçăo. Legislaçăo específica e fontes documentais e arquivísticas (1915-1995). Sâo Luís: MIQCB, 1995.

.Terras tradicionalmente ocupadas: processos de territorializaçăo, movimentos sociais. R. B. ESTUDOS UBANOS E REGIONAIS v. 6, n.1, 2004.

Apresentaçáo. In Direito dos povos e das comunidades tradicionais no Brasil: declaraçóes, convençóes internacionais e dispositivos jurídicos definidores de uma política nacional. Joaquim Shiraishi Neto, org. Manaus: UEA, 2007.

. ALMEIDA; MARIN. Campanhas de desterritorializaçăo na Amazônia: o agronegócio e a reestruturaçăo do mercado de terras. In Amazônia Regiâo universal e teatro do mundo. Willi Bolle, Edna Castro e Marcel Vejmelka (org.).Editora Globo, 2008.

. Quilombos e novas etnias. Manaus: UEA Ediçōes, 2011.

ANTUNES, Marta. As guardiás da floresta do babaçu e o tortuoso caminho do empoderamento. In: Woortmann. Ellen F; Menache, Renata; Heredia, Beatriz (orgs) Margarida Alves. Coletânea sobre estudos rurais e gênero. Brasília: MDA, IICA, 2006.

ASSIS,Wendell Ficher Teixeira. DO COLONIALISMO À COLONIALIDADE: expropriaçâo territorial na periferia do capitalismo. CADERNO CRH, Salvador, v. 27, n. 72, pp. 613627, Set./Dez. 2014

BARBOSA, Viviane de Oliveira. A caminho dos babaçuais: Gênero e imaginário no cotidiano de trabalhadores rurais no Maranhâo. In Coletânea de estudos rurais e gênero.

BARTH, Fredrik. Os grupos étnicos e suas fronteiras. In: $\mathrm{O}$ guru, o iniciador e Outras variaçôes antropológicas. Traduçâo de John Cunha Comeford. Rio de Janeiro: Contra Capa Livraria, 2000.

BOURDIEU, Pierre. 0 poder simbólico. Traduçăo Fernando Tomaz - 11. ed. - Rio de Janeiro; Bertrand Brasil, 2007.

CANOTILHO, J.J. GOMES. Constituiçăo dirigente e vinculaçăo do legislador. 2. ed. Coimbra: Coimbra. 2001

CASTRO-GÓMEZ, Santiago. Ciências sociais, violência epistêmica e o problema da invençáo do outro. In A colonialidade do saber: eurocentrismo e ciências sociais. Perspectivas latino-americanas. Edgardo Lander (org). Colección Sur Sur, CLACSO, Ciudad Autónoma de Buenos Aires, Argentina. Setembro, 2005.

CESAIRÉ, Aimé. Discurso sobre colonialismo. Lisboa: Éditiones Présence Africaine, 1978. 
CHAGAS, Míriam de Fátima. Da invisibilidade jurídica aos direitos de coletividades: fazer antropológico em terra de quilombos. In Desenvolvimento, reconhecimento de direitos e conflitos territoriais. Andrea Zhouri (org). ABA - Associaçăo Brasileira de Antropologia publicaçōes, 2011

CHIVI VARGAS, Idón Moisés. Os caminhos da descolonizaçăo na América Latina: os povos indígenas e o igualitarismo jurisdicional na Bolívia. In Povos Indígenas: Constituiçôes e reformas Políticas na América Latina / [organizador Ricardo Verdum]. - Brasília: Instituto de Estudos socioeconômicos, 2009

COELHO, Elisabeth Maria Beserra. Territórios em confronto: a dinâmica da disputa pela terra entre índios e brancos no Maranhăo. Săo Paulo: Hucitec, 2002.

CRETELLA JÚNIOR, José. As categorias jurídicas e o direito administrativo. Revista de Direito Administrativo, v. 85, pp. 28-33, 2014. Disponível em <http://bibliotecadigital. fgv.br/ojs/index.php/rda/article/viewFile/28805/27657>. Acesso em 27 de setembro de 2014.

DUARTE, Nestor. Comentários sobre Associaçóes. In Código Civil Comentado. César Peluzo (Org). 9. ed. Revista Atualizada, 2015.

DUPRAT, Deborah. 0 direito sob o marco da plurietnicidade/multiculturalidade. In Pareceres Jurídicos - Direito dos Povos e das Comunidades Tradicionais. Deborah Duprat, org. Manaus: uea, 2007.

DUSSEL, Enrique. 1492: O encobrimento do outro. A origem do "mito da Modernidade". Conferências de Frankfurt/Enrique Dussel. Traduçăo Jaime A. Clasen. Petrópolis, RJ: Vozes, 1993.

GIDDENS, Anthony. As consequências da modernidade. Traduçăo: Raul Fiker. Săo Paulo: Editora Unesp, 1991.

FANON, Frantz. Os condenados da terra. Rio de Janeiro: Civilizaçăo Brasileira, 1968

FARIA, Luiz de Castro. Antropologia: Duas Ciências. Notas para uma História da Antropologia no Brasil. Alfredo Wagner Berno de Almeida; Heloísa Maria Bertol Domingues (org). Rio de Janeiro: CNPq/MAST, 2006.

FREYRE, Gilberto. Casa Grande e Senzala, 1933.

GONÇALVES, Maria de Fátima da Costa. A Reinvençăo do Maranhăo Dinástico. Dissertaçăo de Mestrado. Săo Luís. Ediçôes UFMA, 2000

GROSFOGUEL, Ramón. Dilemas dos estudos étnicos norte-americanos: multiculturalismo identitário, colonizaçăo disciplinar e epistemologias descoloniais. Cienc. Cult. [online]. 2007, v. 59, n.2, pp. 32-35.

HOBSBAWM, Eric. Era dos Extremos: o breve século XX: 1914-1991. Traduçăo Marcos Santarrita. Sáo Paulo: Companhia das Letras, 1995.

LEIVAS, Paulo Gilberto Cogo. Teorias dos direitos fundamentais sociais. Porto Alegre: Livraria do Advogado, 2006.

MACIEL, Luciano Moura. As quebradeiras de coco babaçu e o mercado: dilema entre proteçáo dos conhecimentos tradicionais e sujeiçáo jurídica. Dissertaçáo de Mestrado - Manaus, UEA, 2012. 
MARÉS, Carlos Frederico de Souza Filho. Os povos invisíveis. In Direito Constitucional Quilombola: Análises sobre a Açâo Direta de Inconstitucionalidade n. ${ }^{\circ} 3239$. Rio de Janeiro: Editora Lumen Juris, 2015.

MELLO, Marcelo Moura. Reminiscências dos quilombos. Territórios da Memória em uma comunidade negra rural. Campinas: Unicamp. Terceiro Nome. FAPESP. 2012. pp. 33-61.

MENEZES, Elieyd Sousa de. Os "piaçabeiros" no médio rio Negro: identidades coletivas e conflitos territoriais . Dissertaçăo de Mestrado. - Manaus: UFAM, 2012.

MIGNOLO, Walter D. A colonialidade de cabo a rabo: o hemisfério ocidental no horizonte conceitual da Modernidade. In A colonialidade do saber: eurocentrismo e ciências sociais. Perspectivas latino-americanas. Buenos Aires, CLACSO, Consejo Lationamericano de Ciencias Sociales, 2005.

MIGNOLO, Walter D. Desobediência Epistêmica: Retórica de la Modernidad, Lógica de La Colonialidad y Gramática de la Descolonialidad. 1. ed. - Buenos Aires: Del Signo, 2010.

PORRO, NoemiSakiara Miyasaka. Rupture and resistance: gender relations and life trajectories in the babaçu palm forests of Brazil.

PORRO, Noemi Miyasaka;VEIGA, Iran. Caderno de Estudos: A experiência da COOPAESP, ASSEMA e MIQCB com a medida provisória 2186-16 de 2001. Esse Caderno de Estudos versa sobre a experiência da COOPAESP, ASSEMA e MIQCB na relaçáo com a empresa Natura, na perspectiva das lideranças, colaboradores e assessorias.

OLIVEIRA FILHO, Joăo Pacheco de. Ensaios em antropologia histórica: prefácio de Roberto Cardoso de Oliveira: Rio de Janeiro: Editora UFR, 1999.

OLIVEIRA, José Lamartine de. A dupla crise da pessoa jurídica. Sáo Paulo: Saraiva, 1979. QUIJANO, Aníbal. Colonialidad del poder, cultura y conocimiento em América latina. EM ANUARIO MARIATEGUIANO (LIMA: AMAUTA) VOL. IX, n. 9, 1997.

Colonialidade do poder, eurocentrismo e América Latina. In A colonialidade do saber: eurocentrismo e ciências sociais. Perspectivas latinoamericanas. Edgardo Lander (org). Colección Sur Sur, CLACSO, Ciudad Autónoma de Buenos Aires, Argentina. Setembro, 2005.

REIS,Lilia Maria de Oliveira. OS PIAÇABEIROS DE BARCELOS: História de vida e trabalho. Dissertaçăo de Mestrado. PPGSC/UFAM, 2007.

SANTOS, Boaventura de Sousa. Para um novo senso comum: a ciência, o direito e a política na transiçăo paradigmática. - 4. ed. - Sảo Paulo: Cortez, 2002.

SHIRAISHI NETO, Joaquim; DANTAS, Fernando Antônio de Carvalho. Conhecimento tradicional e biodiversidade: normas vigentese propostas. / Alfredo Wagner Berno de Almeida. [et al]. (Orgs.) - 2. ed. - Manaus: ppgas-ufam / nscacestu-uea / uea Ediçōes, 2010

Os quilombos como novos "sujeitos de direito": processo de reconhecimento e impasses. Cadernos UNDB//Săo Luís/v.4. jan/dez 2014.

SOUZA FILHO, Carlos Frederico Marés de. De como a natureza foi expulsa da modernidade. Revista Crítica do Direito, v. 66, pp. 88-105, 2015. 
TÁRREGA, Maria Cristina Vidotte Blanco; GONÇALVES, Daniel Diniz. Fundamentos Teóricos de uma América Latina plural. In Estados e Povos na América Latina Plural/ Organizadores: Maria Cristina Blanco Tarrega. - Goiânia: Ed. Da PUC Goiás, 2016.

WOLKMER, Antonio Carlos. História do direito no Brasil. Rio de Janeiro: Forense, 2002.

\section{DOCUMENTOS}

ASSOCIAÇĀO EM ÁREAS DE ASSENTAMENTO DO ESTADO DO MARANHÂO - ASSEMA. Quem somos? Disponível em 〈http://www.assema.org.br/geral.php?id=Quemsomos〉 Acesso em: 20.04.2011.

BRASIL. SUPREMO TRIBUNAL FEDERAL. PETIÇĀO 3.388 RORAIMA. Brasília. 19-032009. pp. 229-342; pp. 359-418 (Raposa Serra do Sol - RR);

BRASIL. SUPREMO TRIBUNAL FEDERAL. AG.REG. NO RECURSO EXTRAORDINÁRIO COM AGRAVO 803.462 MATO GROSSO DO SUL. Brasília. 09-12-2014.

NÚCLEO DE IMAGEM DE DIREITO E MEIO AMBIENTE - PPGDA/UEA. “Bora, gente!: Direitos e Conhecimento em Movimento. Documentário. In https://www.youtube.com/ watch?v=YBJJhDYBTBs> Acesso em 03 de março de 2017. 